\title{
THE ORIGIN AND THE FOUNDATIONS OF THE PRINCIPLES OF RELIGIOUS EDUCATION
}

\author{
Claudiu Marian Bunăiaşu*
}

\begin{abstract}
The article approaches the issue of the origin of religious education principles, as value foundation of the evolution of general and specific normativiy. This normativity directs the educational process, focusing on the basic ideas of Christian pedagogy, which have become landmarks of life and Christian education. The fundamental ideas belong to the thinking of Church Fathers, Christian philosophers and also to representatives of major systems pedagogical thinking, who had concerns also in christian education filed, of religious education. Some of them have developed theoretical and methodological systems based on principles, values and paradigms of religious education. This relates to current Romanian education reform principles, are detailed in educational situations that facilitate the formation of Christian moral profile of children and young people and are contextualised best educational practices of religious education.

The legitimacy and the opportunity of analyzing the origin of religious education focuses on two perspectives: a) determination and description of axiologicall core of religious education principles crystallized in the history of Christian pedagogy and under the influence of modern and postmodern education developments; b) identification and use of relevant criteria to the development of religious education categories of principles, to guide and regulate the current religious education process .
\end{abstract}

Keywords: religious education, principles of Christian pedagogy, teaching principles, principles of religious education

\section{Axiomatic and conceptual highlights}

In the society and the postmodern school, religious education has the mission to complete the moral-Christian profile of children

\footnotetext{
* PhD, Associate Professor, Faculty of Letters, Department of Communication, Journalism and Education Sciences, University of Craiova, Romania.
} 
and young people, as an essential dimension of the project human development focused on social values and humanistic, desirable in present (human rights, tolerance, empathy, helping, social solidarity, intercultural dialogue, involvement in social projects).

In the field of religious education, the foundation of educational normativity is represented by the compliance with general and specific approach paideutic, including indicative rules, theses, ideas such fundamental Christian teaching, and ethical praxiological, known generically principles of religious education. These principles are outlined and undertaken by educators (teachers, priests, experts, representatives of religious organizations and associations, cultural institutions and educational) In the spirit of faith and veneration of the supreme court transcendent - God On their turn, the principles guiding religious education efforts include principles of Christian pedagogy, teaching principles, principles of organization of education, in general, the religious in particular. These represent norms, rules of action underlying the organization of educational process.

Out of the normativity categories of religious education, the fundamental problem is the principles, they outlin the overall process in the spirit of religious education (formal and nonformal under). Key concepts in the field of religious normativity, which provides the axiological and methodological contextualization of Christian-moral values in educational situations, are derived from general principles of Christian pedagogy and classical pedagogical principles. Principles of Christian pedagogy is a set of fundamental ideas on Christian living standards of educational practices and models, developed based on paideic exemplarity of Jesus Christ, the Christian ideal of reporting human spirit to God.

Pedagogical principles (didactic) are truths most general theory and educational practices, fundamental ideas that guide and regulate the behavior of teaching constant procedural element of continuity that can be found in more situations of teaching, learning 
and assessment ${ }^{1}$. Pedagogical principles fulfill a normative function, of general structural and functional organization of the educational process for the achievement of desirable aims.

The principles of religious education are

„general rules, basic ideas outlined by applying the principles of Christian pedagogy, the main pedagogical and teaching in religious education, which have strategic value and operational for designing, organizing and conducting educational activities, directing the whole process of training man's spiritual, throughacquisition of religious culture and development, affirming sense of connection between man and the court of absolute power and imperturbable $-\mathrm{God}^{2}$.

\section{Ideas and principles of Christian pedagogy of the Church Fathers thought and Christian philosophers}

As we have shown, the principles of religious education are focused and grounded, especially the principles of Christian pedagogy and general principles of the educational process, which resulted in shaping a normativity general area including the fundamental ideas of both Holy Books, the fathers of the Church and of pedagogical thinking. Starting from the premise that religious education is approached as an educational dimension having a integrative character, synthesizing the educational opportunities of the other contents of education and ensuring complementarity and continuity, a first step in shaping the system principles of religious education is the attempt to integrate the principles of education moral, aesthetic education alongside the traditional Christian principles and didactics.

Ideas and principles of Christian pedagogy of thinking of the Church Fathers and Christian philosophers have led to the

\footnotetext{
${ }^{1}$ Constantin Cucoş, Pedagogie, Iaşi, Polirom Publishing House, 2002, p. 347.

${ }^{2}$ Claudiu Marian Bunăiașu, Un sistem taxonomic al principiilor al principiilor educației religioase; implicații asupra demersului paideutic, in: M. C. Stănișoară, G. Florescu, M. Căpraru, C. Stanciu, and A. Pera, Educație și spiritualitate, Craiova, Universitaria Publishing House, 2012, p. 26.
} 
development of educational paradigms, procedural models of internalization of values of Christian Education, highlighted the current role of the precepts of Christian formation of the human person, of which is derived and the principles topical religious education.

Clement of Alexandria (150-215 AD) is the first thinker who expresses the conception of religious education in a systematic educational work. The purpose of education is the salvation by faith and good works of man, and the basic method of salvation is hearing the words of the Pedagogue-Jesus Christ ${ }^{3}$.

Clement of Alexandria describes a series of practical methods of Christian moral education, which favors the objectives of Christian pedagogy: disapproval, reproof advice, admonition, accusation, complaining of fate, irony, example, exercise etc. ${ }^{4}$.

The purpose of Christian education pedagogy of St. Basil the Great (330-379 AD) is preparing for the other life. In this regard, the mission of religious education is spiritual perfection of children by love for God. Educational context favorable to these finalities is the monastery where Christian values are internalized in easy way.

So, besides the principle Christocentric and eclesiocentric specific Christian pedagogy, St. Basil the Great advances pedagogical ideas from which it develops also other principles applied in current pedagogy-the principle of religious issues from multiple perspectives approach, the principle of respect for age and individual peculiarities.

St. Gregory of Nazianz (329-390 AD) laid the foundation of professional pedagogy, focusing on the formation of Church human personality, which is a model of cultural and moral conduct. The

${ }^{3}$ Idem, Conceptii educative şi instituţii de învăţământ în Evul Mediu creştin, in:
"Analele Universităţii din Craiova", History Series, Year XIV, No. 1 (15)/2009,
p. 307. 4 Constantin Cucoș, Istoria pedagogiei. Idei şi doctrine pedagogice fundamentale, Iaşi, Polirom Publishing House, 2001, p. 64. 
basic method is theological meditation on the mystery of God, which helps preserve and enhance theological values.

Human Church Mission derives from a basic rule: ... it is not appropriate to speak anything about God at all times and to everyone, but is a time you have to talk about him ${ }^{5}$. Are highlighted here more pedagogical principles: the principle of unity of action of factors of education, the principle of respect of individual characteristics in religious education, that of accessibility, the continuity in learning ${ }^{6}$.

Pedagogical conception of St. John Chrysostom (344-407 $\mathrm{AD})$ is affirmed in the pedagogical treaty about vainglory and the education of children. The educational ideal is crystallized on values and religious norms, which have grown at all ages. St. John Chrysostom promotes educational ways under psychological peculiarities age and individual based, in children, the education of the senses, personal example, focusing primarily on moralizing and salvation, then the training itself.

In the pedagogical ideas of St. John Hrisostom we can find some pedagogical principles, someof current: the principle of learning throughout life; principle of interdependence between sensory and rational, formative education principle, the principle of respect for age and individual peculiarities principle thorough knowledge of religious rules ${ }^{7}$.

St. Augustine (345-430 AD) promoted a pedagogic system oriented on religious education, based on intuitive methods, encouraging children's curiosity and playful activities ${ }^{8}$. The basic role of the educator is to ensure favorable conditions to stimulate children's interests and knowledge through personal discovery. Augustin promoted pedagogical ideas that advance educational

\footnotetext{
${ }^{5}$ Ibidem, p. 75.

${ }^{6}$ Claudiu Marian Bunăiașu, Concepţii educative şi instituţii de învăţământ în Evul Mediu creştin, in loc. cit., p. 308; Constantin Cucoș, op. cit., p. 75.

${ }^{7}$ Claudiu Marian Bunăiașu, art. cit., p. 309.

${ }^{8}$ Constantin Cucoș, op. cit., p. 83.
} 
systems based on a child's natural development, accentuated in the twentieth century, called the century of the child.

Toma D'Aquino (1225-1274) invoke the support of divinity in education, because man does not have sufficient forces to develop himself. Faith is the essential means of access to knowledge and understanding of unknown things. Educating the will to dominate their nature and cooperation between educator and student in the act of knowledge are essential pedagogical methods. According to Toma D'Aquino, teaching is addressed not simply as a transmission and reception but an uncover truths based on personal actions. This conception methodical anticipated many current pedagogical principles.

\section{Ideas and principles of Christian pedagogy of the representatives of pedagogical thinking}

Representatives of traditional pedagogy completed theoretical fundamental basis outlined by the Church Fathers and Christian philosophers, with important implications on educational practice, which were set up religious education principles, rules and operational rules of practice this educational dimension.

Jan Amos Comenius (1592-1670) laid the foundations of modern teaching and religious education is the promoter of harmonization with other educational dimensions. Starting from the idea that man's ultimate end is beyond this world (All that we are, what we do, we think, talk, us devise, acquire and possess is nothing more than a certain scale that climb the increasingly moreover, to reach as high as possible, without ever we can reach the ultimate stage $^{9}$, God is the beginning and end of all education ${ }^{10}$, Comenius stands for education towards becoming a human rational beings created by the image of the Creator. These properties would be

\footnotetext{
${ }^{9}$ J. A. Comenius, 1970, p. 20, cited in Constantin Cucoş, Educaţia religioasă. Repere teoretice şi metodice, p. 59

${ }^{10}$ Ibidem.
} 
developed by erudition, moral virtues and throug internalizing religious norms. Regarding the last point, the great czech educator approaches Religion not as some object of study, but as a basic principle of organizing the training program of personality.

Theoretician of teaching the principles of classical references work Didactica Magna, Comenius anticipated also ideas, modern principles such as further education or training in interdisciplinary perspective.

Jean-Baptiste de la Salle (1651-1719) analyzed in all his works apect on educating children and training teachers. The concept of the great theologian and educator, education purposes aimed at developing intellectual capacities and behaviors cultivating moral virtues and norms in the spirit of Christian life. Methods of training and education should be focused on the future needs of the children, be rational and have largely practical in nature. Also, training educators is very important, both having this vocation, christian moral virtues and solid training. Educators will use mainly inductive method, which values the child's cognitive experience - a benchmark advanced methodological current curriculum reform.

We find in the ideas of the great theologian and educator Christian, fleshing out several teaching principles: the principle of intuition, the principle of practical education and anticipation of current education reform principles regarding the relevance of education to vocational skills training for teaching care.

Jean-Jacques Rousseau (1712-1778), an outstanding representative of philosophical pedagogy, advocating education for natural religion, God is the object of meditation and support human freedom. The great educator promotes naturalism role in defending child from external influences. The axiom on wich his pedagogical ideas are based is: Everything is good when it comes out of the hand of the Creator; everything degenerates in the hands of man ${ }^{11}$.

11 J.- J. Rousseau, Emil sau despre educaţie, Bucharest, Didactică şi Pedagogică Publishing House, 1973, p. 7. 
Valuable elements of philosophical thinking in religious education pedagogy found in the Treaty of Immanuel Kant (17241804), which highlighted the role of religion in moral formation, citing internalization of norms and religious values from childhood (unlike Rousseau who promote religious education after 18 years). Kant advancing a methodical approach of tangling religious values from the stage of childhood: drawing attention to the natural world order and goals, the need for consistency supreme being

We find again the concratization in the ideas of the great German philosopher, of several pedagogical principles in religious education field: Christocentric principle, the principle of accessibility and continuity in learning systematization principle, the principle of priority formativ and informative educativului to religious education.

Johann Friedrich Herbart (1776-1841) is comitted to religious education developed on principles and philosophical ideas. Educational principle, which was promoted in pedagogy, underlies religious education. In the conception of Herbart, religion courses by integrating specific rules with children's learning experiences acquired through contact with nature and developed their skills in the family. The method could be more attractive based on knowledge supporting the interests of the children. Herbart combat dogmatically teaching religion and coercion.

Analysis of the fundamental ideas of theoretical and practical advanced by Herbart highlights the invoking of principles of religious education and relevant: the principle of priority formative educativ in religious education, the principle of ecumenism, the unity of action of factors of education at the training disciplines.

Maria Montessori (1870-1952), promoter of the method of education based on respect for the rights and freedom of the child in a stimulating environment militated for cultivating faith in God from an early age. After experiencing its own method in a church for children, she developed a methodical system of religious instruction based on gestures applications of behavioral chapel under schemes on practical in nature. Thus, in addition to other pedagogical 
principles, the teacher can assign Italian and advancing the principle of religious education practically utilized in contemporary pedagogy.

\section{A possible taxonomic system of religious education principles}

By correlating axiomatic references to the principles of Christian pedagogy with pedagogical principles of modern and postmodern education, adapted to religious education and with approaches perspectives of religious education in actuality ${ }^{12}$, we have developed into earlier work, a taxonomy consists of two categories of general principles ${ }^{13}$ :

a) didactic principles of religious education, guiding and regulating the teaching of the process of subject religion teaching;

b) specific principles of guidelines of the school curriculum reform and the process of

religious education.

Taxonomic system integrates the following general and specific principles:

\section{1. Specific principles of religious education, a general nature:}

a) The Christocentric principle ;

b) The Eclesiocentric principle ;

c) The principle of Autonomy and respect for religious freedom ;

d) The principle of Ecumenism and interfaith dialogue ;

e) The approach principle of values and norms and multi-religious perspectives and intercultural ;

${ }^{12}$ Constantin Cucoș, Educaţia religioasă. Repere teoretice şi metodice, p. 355363.; E. Macavei, Pedagogie. Teoria educaţiei, Bucharest, Aramis Publishing House, 2002, p. 136-140; I. Maciuc, Pedagogie. Repere introductive, Craiova, Sitech Publishing House, 2006, p. 199-203.

${ }^{13}$ Claudiu Marian Bunăiaşu, Un sistem taxonomic al principiilor educației religioase; implicații asupra demersului paideutic, in: M. C. Stănişoară, G. Florescu, M. Căpraru, C. Stanciu, A. Pera, op. cit., p. 26-27. 
f) The principle of unity of action of educational factors in the achievement of religious education.

\section{2. Religious education principles derived from traditional pedagogical principles:}

a) The principle of respect for age and individual particularities ;

b) The principle of accessibility of knowledge, norms, values and religious dogmas;

c) The princiiple of intuition or interdependence between sensorial and rational, concrete and abstract religious instruction ;

d) The principle of systematization and continuity in learning norms, dogmas and religious values;

e) The principle of conscious participation, active and affective student teaching, learning and assessment;

f) The principle of practice religious education;

g) The principle of sustainable full knowledge and religious norms and values.

\section{3. Principles of religious education under the guidance of curricular reform:}

a) The principle of differentiation and individualization in religious instruction;

b) Educational and formative principle of the priority nature of religious education to look for information;

c) The principle of valuing perspective integrated in the knowledge structures and violation of religious norms and values ${ }^{14}$.

The taxonomic system proposed meets the comprehensiveness characteristic of postmodern didactics, based on the functional relationships between general principles and specific

${ }^{14}$ Ibidem, p. 26-36. 
principles, the assertion of regulatory character on several levels: the Christian life, social relationships, school education, lifelong learning. In terms of teaching, the unitary approach of the principles invoked is the basic condition to ensure their functionality in educational practice and methodological norms properties premise of Christian life in school.

\section{Conclusions}

Principles of Christian pedagogy and religious education is the support axiological and methodological for development of the curriculum formal and nonformal education religious, centered both on the social needs of affirming moral Christian values of the individuals, as well as those individual spiritual fulfillments by targeting actions and thoughts to the Christian ideal. The principles of religious education are operationalized (the norms and rules of action) and contextualised depending on several factors: the skills and craftsmanship educator, peculiarities education, characteristics of religious content, available resources, requirements of didactics subject religion to different stages psychogenic study rhythms learning, homework study, Christian moral conduct targeted.

The functional value of the principles and norms of religious education is the theme of some reflections and future research in the area in several directions: a) the role of principles and values of the religious education in strengthening humanistic approach in education paradigm; b) the approach of religious education from the perspective of postmodern education guidelines; c) arguments concerning the inclusion of religious education curriculum in curricular development of transversal skills desirable in school education and the continuous one. In this sense, an initial step which we expect is a study of the impact on religious education curriculum and strategies for curriculum development, useful in structuring the subject religion and foreshadowing the professional development of teachers of religion. 


\section{Bibliography}

1. Bunăiaşu, Claudiu Marian, Concepţii educative şi instituţii de învăţământ în Evul Mediu Creştin, in: Analele Universităţii din Craiova, History Series, Year XIV, No. 1 (15), 2009, p. 305-314.

2. Bunăiaşu, Claudiu Marian, Un sistem taxonomic al principiilor al principiilor educației religioase; implicații asupra demersului paideutic, in: Stănișoară, M. C., Florescu, G. Căpraru, M. Stanciu, C., Pera, A. Educație și spiritualitate, Craiova, Universitaria Publishing House, 2012, p. 25-38.

3. Cucoş, Constantin, Istoria pedagogiei. Idei şi doctrine pedagogice fundamentale, Iaşi, Polirom Publishing House, 2001.

4. Cucoş, Constantin, Pedagogie, Iaşi, Polirom Publishing House, 2002.

Cucoş, Constantin, Educaţia religioasă. Repere teoretice şi metodice, Iaşi, Polirom Publishing House, 2009.

5. Cucoş, Constantin, Educaţia religioasă. Repere teoretice şi metodice, Iaşi, Polirom Publishing House, 2009.

6. Kant, Immanuel, Tratat de pedagogie. Religia în limitele raţiunii, Iaşi, Agora Publishing House, 1992.

7. Maciuc, I., Pedagogie. Repere introductive, Craiova, Sitech Publishing House, 2006.

8. Macavei, E., Pedagogie. Teoria educaţiei, Bucharest, Aramis Publishing House, 2002.

9. Rousseau, J.- J., Emil sau despre educaţie, Bucharest, Didactică şi Pedagogică Publishing House, 1973. 